\title{
NÓS, OS OUTROS: EL OTOÑO DEL PATRIARCA ${ }^{1}$
}

Pedro Mandagará ${ }^{2}$

Resumo: Neste texto faço uma leitura do romance El otoño del patriarca, de Gabriel García Márquez. A fortuna crítica do romance, em especial a recepção imediatamente posterior ao seu lançamento em 1975, serve como fundamento para uma leitura dos papéis do narrador e do protagonista do romance. Apresento uma leitura do narrador do romance que difere das duas interpretações críticas mais recorrentes. Ao final do texto trato do protagonista do romance, mostrando sua inserção histórica-alegórica na realidade latinoamericana.

Palavras-chave: Narrador; Romance latino-americano.

Abstract: This is a reading of Gabriel García Márquez's The Autumn of the Patriarch. The history of the novel's readings, particularly those published right after the novel's 1975 publication, is the basis of a reading of the roles of the novel's narrator and of its protagonista. I present a reading of its narrator that is different from the two most common critical interpretations. The last part of this text is about the novel's protagonist, and it shows its historical-allegorical insertion into Latin-American reality.

Keywords: Narrator; Latin-American Novel.

\footnotetext{
${ }^{1}$ Uma versão inicial deste trabalho se encontra na tese de doutorado do autor.

${ }^{2}$ Possui graduação em Bacharelado em Filosofia pela Universidade Federal do Rio Grande do Sul (2005), mestrado em Lingüística e Letras pela Pontifícia Universidade Católica do Rio Grande do Sul (2008) e doutorado em Letras pela Pontifícia Universidade Católica do Rio Grande do Sul (2012). Atualmente é professor adjunto da Universidade de Brasília. Tem experiência na área de Letras, com ênfase em Teoria Literária, atuando principalmente nos seguintes temas: literatura brasileira, história da literatura, literatura comparada. E-mail: pedromandagara@unb.br
} 


\section{Um novo Cien años de soledad?}

A publicação de Cien años de soledad, em 1967, catapultou Gabriel García Márquez para a fama instantânea. Até então, era um autor muito pouco conhecido mesmo dentro de sua Colômbia natal - seus três romances anteriores (La hojarasca, de 1955, El coronel no tiene quién lo escriba, de 1958, e La mala hora, de 1962) e seu livro de contos (Los funerales de la Mamá Grande, de 1962) não tiveram quase vendagem, apesar de alguma atenção crítica (Shaw, 2010: p. 25).

A partir de 1967 e da instantânea consagração de público e crítica de Cien años de soledad, criou-se uma expectativa quanto ao próximo romance de García Márquez. Nos anos subsequentes ele publicou um livro-reportagem (Relato de un náufrago, de 1970), dois outros que recolhiam crônicas e reportagens (Cuando era feliz e indocumentado, de 1973, e Chile, el golpe y los gringos, de 1974) e dois livros de contos (La increíble y triste historia de la cándida Eréndira y de sua abuela desalmada, de 1972, e Ojos de perro azul, de 1973). Boa parte dessa produção, no entanto, recolhia escritos anteriores a Cien años de soledad.

Consta, de fato, que García Márquez vinha escrevendo El otoño del patriarca, de maneira intermitente, desde antes de Cien años de soledad. Segundo a biografia de Gerald Martin, em 1962 o escritor colombiano havia escrito trezentas páginas de uma primeira versão do romance, que abandonou (201, p. 351). Essa versão também se encontra no seu longo depoimento a Plinio Apuleyo Mendoza, El olor de la guayaba, onde acrescenta que, dessa primeira versão, só se salvou o nome do personagem (1996, p. 49) - ou seja, nada, já que o nome do Patriarca nunca é mencionado no romance. No mesmo depoimento, menciona-se uma versão intermediária, iniciada em 1968, em Barcelona, e também interrompida. García Márquez só voltaria ao romance após ler um livro sobre a caça de elefantes e concluir que estes traziam uma nova chave à moralidade do seu protagonista (p. 50). ${ }^{3}$

\footnotetext{
${ }^{3}$ A história dos elefantes como chave para o Patriarca soa como uma das tantas mistificações pelas quais García Márquez era famoso - mas deve-se notar que, nas descrições físicas do Patriarca, os elefantes aparecem como termo de comparação para seus pés e, por extensão, para seu andar. As características "bestiais" do corpo do Patriarca são estudadas no artigo de Tim Richards, "El patriarca rabelesiano (la desmitificación de la dictadura a través del cuerpo grotesco)" (1988).
} 
O lançamento de El otoño del patriarca, em 1975, foi acompanhado de uma imensa publicidade internacional. Trechos do romance foram publicados previamente em diversos veículos, como na New Yorker e no Cadernos de Opinião. No entanto, a recepção não foi das melhores. Conforme o testemunho de Flávio Moreira da Costa, no Pasquim, "virou moda malhar seu último romance ( $O$ outono do patriarca), pois todo o mundo tava esperando um Cem anos de solidão - Part Two (1975, p. 17).

Esperava-se realmente uma sequência, algo mais no estilo de Cien años de soledad. Segundo Eduardo Gonzáles Bermejo, em entrevista com Márquez publicada no Cadernos de Opinião, o escritor uruguaio Juan Carlos Onetti teria dito que "Cem anos de solidão tinha que pesar muito em teu trabalho do Patriarca", e que Márquez "não devia ter se preocupado em dar ao Patriarca um tratamento diferente do de Cem anos" (Márquez, 1975a, p. 51). Bermejo assegura na entrevista que Onetti não era o único a ter expressado esta opinião, e parece não ter sido mesmo. Dois anos após a publicação do romance, o jornalista Luis Pancorbo, que comparou El otoño a outros dois romances sobre ditadores ${ }^{4}$ para a espanhola Revista de Occidente, pergunta em seu artigo: "que houve com aquela novidade, com aquele frescor [de Cien años de soledad]?" (1977, p. 15).

García Márquez dizia que seu objetivo era exatamente se afastar das obras anteriores. Ao explicar o aspecto poético de El otoño, numa entrevista publicada pela primeira vez em 1977 no jornal colombiano El Manifiesto, Márquez diz que "é um luxo que um escritor que escreveu Cem anos de solidão pode ter, dizer, bem, agora vou escrever o livro que eu quero" (BELLVILLADA, 2006, p. 90-91). Na mesma entrevista, Márquez ainda fala da pressão por fazer um novo Cien años de soledad, em termos muito próximos aos de Flávio Moreira da Costa: "Eu poderia ter continuado escrevendo Cem anos de solidão, a sequência, II, III, IV, como O poderoso chefão. Mas não podia ser." (p. 91) Na sua famosa entrevista à Playboy norte-americana, em 1982, ele clarifica ainda mais a questão:

\footnotetext{
${ }^{4}$ Tratam-se de El recurso del método, de Alejo Carpentier, e Yo, el supremo, de Augusto Roa Bastos. No artigo, o jornalista expressa sua preferência pelo romance de Carpentier (p. 12). Existem inúmeros textos que comparam os três romances, publicados em datas muito próximas e todos com um ditador latinoamericano como protagonista. Um livro que merece destaque, e que me ajudou muito na pesquisa bibliográfica deste artigo, é Romance de um ditador: poder e história na América Latina (1989), de Márcia Hoppe Navarro, estudo que ganhou o prêmio Casa de las Americas.
}

|34| Revista Eletrônica Literatura e Autoritarismo, oo 27 - janeiro a junho de 2016 - ISSN 1679-849X http://cascavel.ufsm.br/revistas/ojs-2.2.2/index.php/LA/index 
Honestamente, eu não entendo por que tantas pessoas queriam que $\mathrm{O}$ outono do patriarca fosse como $\mathrm{Cem}$ anos de solidão. Suspeito que, se eu quisesse sucesso comercial, poderia ter continuado escrevendo $\mathrm{Cem}$ anos de solidão pelo resto da minha vida. Eu poderia trapacear, como eles fazem em Hollywood: O retorno do Coronel Aureliano Buendía. (2006, p. 127)

Apesar do conteúdo explicitamente político do romance, García Márquez não via sua obra como engajada. Em El olor de la guayaba, o escritor colombiano se diz um homem engajado (comprometido) pelo socialismo, ${ }^{5}$ mas que:

tenho muitas reservas sobre o que entre nós acabou se chamando literatura engajada (comprometida), ou mais exatamente o romance social, que é o ponto culminante desta literatura, porque me parece que sua visão limitada do mundo e da vida não serviu, politicamente falando, para nada. (1996, p. 85)

Note-se, no entanto, que a ideia subjacente de literatura engajada parece mais ligada ao realismo socialista de Zhdanov do que ao engajamento conforme defendido por Sartre.

Apesar de mais curto que Cien años de soledad, El otoño foi criticado pelo suposto exagero de sua extensão. Numa resenha da tradução brasileira do romance, o crítico Jorge Escosteguy escreveu na revista Veja: "García Márquez esbarrou no dilema do jornalista que encontrou um material rico demais para trabalhar e não soube como sintetizar sem pecar pelo excesso de exemplos e situações." (1976, p. 111). Da mesma forma, Gemma Roberts lastimou, na espanhola Revista de Archivos, Bibliotecas y Museos, que García Márquez não tivesse feito uma obra mais breve, sem o "verbalismo fatigante" de algumas das páginas de El otoño (1976: p. 196). Kessel Schwartz afirmou em sua breve resenha para a revista norte-americana Hispania que o romance "nos oferece mais uma versão do falatório ocioso que caracteriza os últimos

\footnotetext{
${ }^{5}$ No entanto, na entrevista à Playboy, García Márquez diz que não é comunista (Bell-Villada, 2006: p. 97). A aparente contradição pode ser contornada pensando que, no léxico de Márquez, a palavra comunismo parece muito mais ligada à União Soviética e aos países que adotavam o modelo soviético, dos quais o escritor colombiano era crítico desde sua visita à Alemanha Oriental e à União Soviética em 1957, e a palavra socialismo mais ligada à alternativa cubana, que nunca deixou de admirar.
} 
trabalhos de muitos dos maiores romancistas hispano-americanos atuais." (1976, p. 557).

No entanto, o romance também foi criticado por ser excessivamente sintético. Mario Benedetti, em seu "El recurso del supremo patriarca", publicado na Revista de Crítica Literaria Latinoamericana, aponta a falta de "períodos de descanso" no romance (1976, p. 60). Para Benedetti, o romance é exagerado não em termos de extensão textual, mas do uso excessivo da hipérbole como artifício narrativo. A "desmesura" (falta de medida) seria o problema central do romance. De tão malvado, o Patriarca acabaria sendo um personagem inverossímil. (p. 60)

Se Benedetti acha o Patriarca inverossimilmente mau, também se disse que García Márquez estaria humanizando em excesso a figura do ditador. Julio Jamón Ribeyro, na revista colombiana Eco, escreve que "Esse velhote de idade imemorial [...] tão divertido e imaginativo inclusive em seus crimes, não inspira repulsa. Por vezes é realmente encantador." (1975, p. 102) O problema, para Ribeyro, é que ao adotar "o partido do ameno", García Márquez correu o risco de "fazer não a crítica mas a glorificação do ditador" (p. 103). Para o crítico norte-americano Michael Wood, escrevendo na The New York Review of Books, García Márquez parece estar dizendo que, na realidade, não é tão divertido ser um ditador e viver tão isolado em seu poder, o que the parece muito semelhante à visão de que "dinheiro não traz felicidade" (1976, p. 58).

A posição do próprio García Márquez parecia ser um pouco mais ambivalente. Ao falar, em El olor de la guayaba, sobre o paralelo entre a solidão do poder e a solidão da fama, que, ambas, levariam a um problema de comunicabilidade e um isolamento do mundo exterior, ele diz:

A grande pergunta no poder e na fama seria portanto a mesma: "Em quem acreditar?" A qual, levada a seus extremos delirantes, teria que conduzir à pergunta final: "Quem diabos sou eu?" ("Quién carajo soy yo?") A consciência deste risco, que não teria conhecido se não fosse um escritor famoso, é claro que me ajudou muito na criação de um patriarca que já não conhece, talvez, seu próprio nome. $\mathrm{E}$ é impossível, neste jogo de ida e volta, de toma-lá e dá-cá, que o autor não termine por ser solidário com seu personagem, por muito detestável que este pareça. Ainda que seja somente por compaixão. (1996: p. 129-130) 
Assim, para Márquez, a questão não é se o Patriarca é excessivamente monstruoso ou humanizado em excesso: mesmo detestável, o Patriarca gera compaixão no autor, pela solidão absoluta do poder. Esta visão dupla do ditador, que entre detestável e merecedor de compaixão, pode ser extrapolada para o polo do leitor.

Resenhas positivas foram nesta mesma linha apresentada pelo autor, concentrando-se no romance como análise do poder. Luis Iñigo Madrigal, no jornal espanho Triunfo, (1975, p. 72) lê o romance como reflexão sobre o poder, e Dasso Saldivar, na também espanhola La Estafeta Literaria (1975, p. 5 ), defende que o romance, mais que obra social ou política, é "una gran obra filosófica", por conta desta reflexão. Esta última resenha, publicada na edição de 1 de abril de 1975 da revista, foi das primeiras a sair sobre o romance afinal, este fora lançado em março.

A questão linguística também foi levantada como positiva. $O$ escritor norte-americano Paul West, escrevendo na revista apropriadamente intitulada Review, elogiou o estilo e a técnica narrativa do romance, pois no romance se você "tenta descobrir o que está acontecendo (...) acaba com uma noção melhor do contexto do evento do que do evento ele mesmo. Simplesmente não é esse tipo de romance" (1976, p. 77).

\section{O narrador plural}

El otoño del patriarca é composto por seis capítulos, cada um contendo apenas um parágrafo. Os capítulos-parágrafo começam narrados por uma voz em primeira pessoa do plural. O início do primeiro capítulo narra a descoberta do cadáver do Patriarca por essa voz plural, e no início de cada capítulo subsequente se volta a essa cena.

Partindo do momento da morte definitiva do Patriarca, a narração volta ao início de seu Outono, coincidente com sua "primeira morte" - na verdade a morte de seu sósia, Patricio Aragonés. Os capítulos seguem o Outono, isto é, o processo de decadência do Patriarca, de maneira cronológica - o que não é tão fácil de perceber, pelo uso intenso de recursos temporais na narrativa.

A voz na primeira pessoa do plural serve de moldura ao romance e aos capítulos individuais, mas diversas outras vozes surgem e desaparecem sem Revista Eletrônica Literatura e Autoritarismo: Narrativa Testemunhal e Relações Históricas - ISSN 1679-849X |37| http://cascavel.ufsm.br/revistas/ojs-2.2.2/index.php/LA/index 
aviso. Fora algumas poucas frases curtas, como no início do primeiro capítulo, a maior parte do romance compõe-se de frases longuíssimas, que comportam em si diversas vozes, assuntos e tempos. A maior das frases, por exemplo, compõe a totalidade do sexto e último capítulo, o que dá 67 páginas na edição que utilizo, da editora Club Bruguera (1980). ${ }^{6}$ Dentre as vozes secundárias, a que mais aparece é do próprio Patriarca, mas outros personagens também falam.

A identidade da voz narrativa plural é um ponto polêmico na fortuna crítica do romance. Existe um problema em integrar esse "nós" a qualquer grupo coerente. A princípio, o "nós" parece ser o grupo determinado de quem encontra o cadáver do Patriarca após sua morte definitiva, mas a voz plural também é usada para incluir os trabalhadores domésticos da casa do Patriarca e até mesmo seu conselho de ministros. O problema se agrava se entendermos que o "nós" é a soma das vozes que aparecem no romance, excluindo a do Patriarca.

Duas soluções críticas se destacam sobre a caracterização do narrador de El otoño del patriarca. A primeira delas identifica o narrador plural à voz do povo oprimido pelo Patriarca. É a posição de Ángel Rama em Los dictadores latinoamericanos (1976, p. 65). Outra interpretação, adotada por Julio Ortega (1978), Roberto Echevarría (1980) e Jo Labanyi (1987), enfatiza a incoerência da voz narrativa, mostrando que nada corresponde ao "nós" que fala. Nessa interpretação, o "código da escritura" vai se sobrepor ao "código do narrador plural" como sustentáculo da narrativa (Ortega). Mais do que atacar a ditadura, o romance atacaria "a ditadura da retórica", o que quer dizer, o domínio da retórica da forma romanesca (Echevarría):

Somos nós [?] uma segunda pessoa sendo interpelada pelo texto, uma primeira pessoa que adentra o texto para colocá-lo em ordem, ou uma terceira pessoa impassiva, que apenas assiste? Quem [é, são] [tu, eu, nós]? Sem pessoas, ou com múltiplas pessoas a quem faltam um estatuto ontológico claro mesmo em termos representacionais - ou identidade gramatical, não há ninguém para reconstruir um texto que está simplesmente aí, como a mais devastadora crítica da ditadura além das mais óbvias mensagens políticas do autor. (Echevarría, 1980, p. 214.)

\footnotetext{
${ }^{6}$ E 49 páginas na tradução brasileira publicada pela editora Record (1993).
}

|38| Revista Eletrônica Literatura e Autoritarismo, № 27 - janeiro a junho de 2016 - ISSN 1679-849X http://cascavel.ufsm.br/revistas/ojs-2.2.2/index.php/LA/index 
O leitor tem que enfrentar o fato inquietante de que a história que ele vem lendo, como um desenho de Escher, é retratada desde uma perspectiva inconsistente, de fato impossível. (...) A implausibilidade da voz que fala destrói a autoridade do que é dito. (LABANYI, 1987, p. 147)

As leituras de Ortega, Echevarría e Labanyi têm uma base fortemente pós-estruturalista, e, como tal, enfatizam a relação entre linguagem e poder no romance. O "outono" do Patriarca se identifica com a substituição da voz pela escrita, quando Leticia Nazareno alfabetiza o Patriarca (Labanyi) ou com a substituição de sua presença por uma "re-produção" (Echevarría), por exemplo quando José Ignacio Sáenz de la Barra forja comunicados televisivos do Patriarca a partir de montagens de vídeos antigos onde este aparecia.

No lado oposto, a interpretação de Ángel Rama - de que o "nós" se refere ao "povo" - tem uma forte sustentação no final do romance, nas últimas páginas da imensa frase que corresponde ao sexto capítulo. Nelas, o narrador plural parece se colocar ao lado das "muchedumbres frenéticas"7 que saúdam a morte do ditador e o fim do "tiempo incontable de la eternidad"8 (Márquez, 1980, p. 344).

Tomando a noção de "narrativa de encaixe", de Mieke Bal, podemos pensar que esse "nós" narra o todo da história, e que outros discursos estão "encaixados" na narração do "nós". Restaria saber, aí, a função de cada "encaixe". Boa parte deles são diálogos ou falas de personagens, ou discurso indireto livre. Em se tratando de uma narrativa convencional, poder-se-ia perguntar qual o acesso do narrador a tais discursos - se o "nós" estava presente, ouvindo o diálogo narrado, ou se alguma forma indireta de acesso ocorreu (uma narração intermediária).

Esta segurança da narração tradicional falta a El otoño del patriarca. Algumas frases do Patriarca podem ter sido ouvidas pelo narrador, como, por exemplo, os bordões que acompanham alguns personagens ("mi compadre de toda la vida el general Rodrigo de Aguilar", p. 22, ou "Manuela Sánchez de mi mala hora", "Manuela Sánchez de mi desastre", "Manuela Sánchez de mi

\footnotetext{
7 "multidões frenéticas" (1993: p. 254)

8 "tempo incontável da eternidade" (1993: p. 254)
}

Revista Eletrônica Literatura e Autoritarismo: Narrativa Testemunhal e Relações Históricas - ISSN 1679-849X http://cascavel.ufsm.br/revistas/ojs-2.2.2/index.php/LA/index 
locura", p. 91). ${ }^{9}$ Sua função não seria de citar literalmente o Patriarca, mas de certa forma parodiá-lo, a partir de características marcantes de sua discursividade.

No entanto, há diálogos que com certeza não poderiam ter sido ouvidos por narrador algum, como as conversas do Patriarca com sua mãe Bendición Alvarado, ou a conversa que ele tem no leito de morte de seu sósia Patricio Aragonés (diálogo narrado numa única frase de quatro páginas - 35 a 39). ${ }^{10}$ Nesses momentos, a voz narrativa alcança onisciência, e o "nós" parece dar lugar a um narrador em terceira pessoa.

Se o "nós" que encontrou o cadáver do Patriarca não poderia ter acesso a seus diálogos, muito menos teria a sensações e pensamentos. Ao longo do primeiro capítulo do romance, a narrativa se aproxima mais e mais da vida mental do Patriarca. No início, suas sensações são apenas mencionadas: "lo inquietó la ilusión de que las cifras de su proprio destino estuvieran escritas en la mano del impostor" (p. 19. Grifo meu). ${ }^{11}$ Porém, logo chegamos ao pensamento do Patriarca: "pensando madre mía Bendición Alvarado si supieras que ya no puedo con el mundo, que quisiera largarme para no sé dónde, madre, lejos de tanto entuerto" (p. 32). ${ }^{12}$ A palavra "pensando" marca o discurso do narrador, que introduz a consciência do Patriarca.

Há um movimento, lento no primeiro capítulo e mais rápido nos seguintes, que vai do nós que encontra o cadáver do Patriarca e relembra sua história a uma espécie de narrador onisciente em terceira pessoa. A transição não é feita de forma clara: simplesmente o pronome, nós ou nosotros, deixa de aparecer, substituído por uma espécie de voz neutra. Em três dos capítulos no primeiro, no terceiro e no sexto - o pronome "nós" volta ao final do capítulo, mas apenas no último é o mesmo "nós" que encontra o cadáver do Patriarca no início do romance. O "nós" que aparece ao final do primeiro capítulo conta ao Patriarca a chegada das três naus de Cristóvão Colombo ao país, numa inversão paródica das cartas de descoberta da América que substitui 0

\footnotetext{
9 "meu compadre de toda a vida o general Rodrigo de Aguilar" (1993: p. 16), "Manuela Sánchez da minha desgraça", "Manuela Sánchez dos meus pecados" e "Manuela Sánchez da minha loucura" (p. 67).

${ }^{10} \mathrm{Na}$ edição brasileira, da 27 à 29.

11 "inquietou-o a ilusão de que os números do seu próprio destino estivessem escritos na mão do impostor." (p. 14)

12 "pensando minha mãe Bendición Alvarado se soubesse que já não posso com o mundo, que gostaria de ir para não sei onde, mãe, longe de tanta coisa errada" (p. 24)
}

|40| Revista Eletrônica Literatura e Autoritarismo, no 27 - janeiro a junho de 2016 - ISSN 1679-849X http://cascavel.ufsm.br/revistas/ojs-2.2.2/index.php/LA/index 
narrador europeu por um "nós" que representa a voz indígena silenciada (conforme Brotherston, 1979, e Córdova, 1984). No caso do terceiro capítulo, o "nós" é a voz dos ministros que conspiraram com o general Rodrigo de Aguilar para derrubar o Patriarca do poder, presentes num jantar onde o corpo do general é servido assado, "macerado en especiarias, dorado al horno, (...) catorce libras de medallas en el pecho y una ramita de perejil en la boca" ( $p$. 161), ${ }^{13} \mathrm{e:}$

ante la petrificación de horror de los invitados que presenciamos sin respirar la exquisita ceremonia del descuartizamento y el reparto, y cuando hubo en cada plato una ración igual de ministro de la defensa con relleno de piñones y hierbas de olor, él dio la orden de empezar, buen provecho señores. (p. 162) $)^{14}$

Nessa passagem se pode perceber a rapidez das transições narrativas: mencionados, "los invitados" (os ministros) assumem o discurso, e não fica claro se o devolvem ao narrador anterior na oração seguinte. Todo o trecho que começa com "y cuando hubo..." e que termina com "empezar" tem um estatuto narrativo incerto, podendo ter sido enunciado pelos ministros, pelo "nós" narrador do início do romance, ou por essa voz neutra e onisciente que tem acesso aos pensamentos das personagens. Ao final do trecho ainda temos a voz do Patriarca em discurso direto.

Além da incerteza quanto ao estatuto das vozes que podem ou não ter sido retomadas pelo narrador, temos as vozes que são retrospectivamente atribuídas a uma situação de diálogo, geralmente por meio de um vocativo. Um exemplo particularmente complexo pode ser visto neste trecho:

el único que consiguió desentrañar de su remota guarida de los páramos al legendario general Saturno Santos, un indio puro, incerto, que andaba siempre como mi puta madre me parió con la pata en el suelo mi general porque los hombres bragados no podemos respirar si no sentimos la tierra (p. 78. Grifos meus. $)^{15}$

\footnotetext{
13 "macerado em temperos, dourado ao forno, (...) catorze libras de medalhas no peito e um raminho de salsa na boca" (p. 120)

14 "ante a petrificação de horror dos convidados que presenciamos sem respirar a extraordinária cerimônia do esquartejamento, e da divisão, e quando houve em cada prato uma porção igual de ministro da defesa com recheio de amêndoas e cheiro-verde, ele deu a ordem de começar, bom proveito senhores." (p. 120)

15 "o único que conseguiu desentocar de sua remota guarida dos páramos o general Saturno Santos, um índio puro, falso, que andava sempre com a puta que me pariu com os pés no chão meu general porque nós homens duros não podemos respirar se não sentimos a terra" (p. 57)
} 
Neste trecho, a voz narrativa principal, um "nós" ("podemos"), mostra estar em diálogo com o Patriarca por meio do vocativo "mi general", que, retrospectivamente, altera o sentido do discurso anterior. Esse "nós" pode ou não ser o "nós" narrador do início do romance: pela situação, fica implícita a possibilidade de se referir a soldados da guarda presidencial, que estão fazendo um relatório do que acontece com os generais da guerra federal que ajudaram o Patriarca a subir ao poder e que este agora tenta eliminar. No trecho, ainda é citado o discurso de um "eu", que pode ser o general Saturno Santos: "como mi puta madre me parió". A situação se torna ainda mais complicada pelos dois personagens, o índio Saturno Santos e o Patriarca, serem ambos "generais".

O complexo tecido discursivo do romance convida ao uso de noções como a de bricolage, de Lévi-Strauss, ou a de texto escrevível, de Barthes, numa leitura do romance onde unidades textuais flutuam sem hierarquia, vozes destacadas de sua enunciação, umas ao lados das outras, como num álbum. Essa leitura é indicada e realizada diversas vezes na fortuna crítica, correspondendo, em diversos graus de radicalidade, aos citados Ortega, Echevarría e Labanyi.

\section{Nos+otros}

Proponho, no entanto, uma terceira alternativa de leitura, que se afasta tanto da dissolução do narrador numa textualidade solta quanto da identificação simples com o povo. Minha leitura implica recomeçar a análise de outra forma, a partir do pronome "nós" (nosotros) em si.

$\mathrm{Na}$ etimologia do idioma espanhol, nosotros se compõe de nos + otros. Segundo o Diccionario crítico etimológico de la lengua castellana, de J. Corominas (1954), o pronome serve, "inicialmente, para dar ênfase à oposição entre a pessoa a quem se fala e o grupo ao qual pertence o falante" (p. 523), razão pela qual também existiria vosotros. O nos, no caso, indica uma forma arcaica da primeira pessoa do singular. Nosotros, portanto, compõe-se de eu mais os outros.

Porém, quem são os outros? 
No primeiro volume dos seus Problemas de linguística geral, Émile Benveniste define o pronome nós como junção de eu e não-eu. O não-eu subdivide o nós em duas possibilidades: o nós inclusivo (eu + segunda pessoa, tu ou vós) e o exclusivo (eu + terceira pessoa, ele ou eles). Diversas línguas, como o guarani, ${ }^{16}$ usam pronomes diferentes para os dois tipos de nós (1995, p. 256$)^{17}$.

A origem etimológica do nosotros parece indicar um nós exclusivo: se nosotros serve para opor eu e meu grupo ao meu interlocutor, este não pode estar incluído no grupo a que me refiro com o pronome. No entanto, ainda segundo Benveniste, as línguas indo-européias (das quais o espanhol faz parte) não funcionam, ou pelo menos não funcionam mais, assim. Nelas, o nós é um tipo de eu estendido e amplificado, como se pode perceber no plural majestático e no nós utilizado em textos acadêmicos.

Para responder a questão do "nós" que narra o romance, restaria perguntar quem é este: eu e os outros (e quais outros, os que estão comigo ou aqueles com quem falo)? Eu estendido?

Creio que o "nós" que narra El otoño del Patriarca usa a estrutura do nós "eu + outros" das línguas ameríndias, não a do "eu estendido" das línguas indoeuropéias. O argumento para a segunda estrutura seria a de que o "nós" encobriria o funcionamento de um "eu" que tudo comandaria, à maneira do plural majestático. Esta estrutura, embora possível, não é empregada em El otoño del patriarca. A voz narradora do romance deixa implícita divergências dentro da multiplicidade de seu "nós", com expressões do tipo "hasta los menos cándidos esperábamos" (Márquez, 1980: p. 163). ${ }^{18}$ A sutil referência implica uma divisão dentro do "nós", que passa a conter pelo menos dois grupos, divididos por serem mais ou menos cândidos.

Há, ainda, divisões mais profundas que esta - já que, como mencionamos na seção anterior, o "nós" é utilizado não só para o grupo que descobre o corpo do Patriarca quando de sua morte definitiva, como para o grupo que entra em contato com Colombo no final do primeiro capítulo, ou para

\footnotetext{
${ }^{16}$ Conforme informação de Hugo Achugar em sua conferência no XI Seminário Internacional de História da Literatura, que ocorreu na PUCRS em Porto Alegre, em outubro de 2011.

${ }^{17}$ Ao usar este texto de Benveniste sigo Barsy (1989, p. 195), que também usa Benveniste para explicar o narrador do romance, embora nossas leituras tenham caminhos diversos.

18 "até os menos cândidos esperávamos" (p. 121).
}

Revista Eletrônica Literatura e Autoritarismo: Narrativa Testemunhal e Relações Históricas - ISSN 1679-849X http://cascavel.ufsm.br/revistas/ojs-2.2.2/index.php/LA/index 
o conselho de ministros presentes ao banquete canibal do final do terceiro. Dado isso, quero propor que a voz narrativa de El otoño del patriarca não só não é um "eu" disfarçado indo-europeu, como subverte o sentido etimológico do nosotros espanhol. A saber, nosotros não seria nos (= singular) + otros, mas nos (= plural), los otros - nós, os outros.

O nosotros de El otoño del patriarca está, em minha leitura, diretamente identificado com a posição dos otros - no romance, uma posição móvel que inclui os súditos do poder (o povo), mas também conspiradores ou mesmo apoiadores. Conforme muda a correlação política em torno do Patriarca, muda quem são nosotros.

Além disso, quero chamar atenção para outra função do "nós", quando usado pelo narrador. O "nós" pode ser usado não só como referindo à pluralidade de personas fictícias que narram a história, como pode se referir à união entre narrador e leitor. O "nós", nesse sentido, funciona como convite: que o leitor entre no time de nosotros. O leitor implícito de García Márquez, portanto, é convidado, por meio do uso do narrador-nós, a fazer parte dos otros, isto é, da comunhão daqueles que se encontram afastados do poder uma posição móvel, na qual diferentes solidariedades e resistências se estabelecem.

\section{O patriarca sem nome}

Em O controle do imaginário (2007), Luiz Costa Lima defende a tese de que uma barreira à ficcionalidade operou no campo intelectual de matriz européia no Renascimento e nos primórdios da modernidade. Os textos sobre literatura daquele momento histórico, que seriam uma produção somente superada em volume no século $\mathrm{XX}$, interpretariam a mimesis aristotélica a partir do modelo da imitatio latina, isto é, como reprodução da realidade e não como criação. A história da "libertação" da ficcionalidade é longa, tortuosa e contraditória, mas Costa Lima apresenta o Romantismo como seu ponto fundamental.

Num raciocínio que apresenta muitos paralelos ao de Costa Lima, Catherine Gallagher, no seu artigo "Ficção" (2009) - parte do volume coletivo $A$ cultura do romance, organizado por Franco Moretti - defende que somente no |44| Revista Eletrônica Literatura e Autoritarismo, № 27 - janeiro a junho de 2016 - ISSN 1679-849X http://cascavel.ufsm.br/revistas/ojs-2.2.2/index.php/LA/index 
século XVIII a ficção se une à narrativa longa. A autora usa a distinção anglosaxônica entre romance e novel - dos quais o primeiro termo se refere a novelas episódicas anteriores ao século XVIII, o que incluiria, por exemplo, o picaresco, e o segundo termo equivale ao que chamamos de romance. No romance - nas novelas episódicas - existe uma interdição a se tratar ficcionalmente da vida cotidiana: ou se tratam de acontecimentos fantásticos e espetaculares, ou se assume que a narrativa se refere a fatos reais. Assim, um autor de transição como Defoe apresenta a história de Robinson Crusoe como verdadeira, insistindo em sua veracidade - o que não é um artifício metaficcional como os que ficariam famosos no século $X X$, com Borges e Umberto Eco, mas um jogo com as expectativas do público da época, que efetivamente esperaria que esta história fosse verdadeira.

Dentro deste contexto, romances que tratavam da vida cotidiana usualmente nomeavam os personagens de forma alegórica, ou usando apenas iniciais, ou nomes descritivos como "M. Ingrat" ou "duquesa de L'Inconstant" (p. 647). Muitas dessas narrativas eram identificadas com o gênero das chroniques scandaleuses, narrativas supostamente reais que contariam "escândalos" da sociedade.

Para que a ficcionalidade entrasse também no terreno da narrativa sobre o cotidiano, os primeiros romancistas ingleses, como Richardson e Fielding, tiveram de pôr nomes próprios em seus personagens, como maneira de individualizá-los para além de características morais e alegóricas. O nome "Tom Jones" não diz nada de muito específico sobre o personagem, apenas diz que ele é alguém único: temos de ler o romance para descobrir quem, afinal, é este personagem único, o que o define, quais seus hábitos e características, etc.

O nome próprio tornou-se uma técnica de individuação de personagens e uma maneira de hierarquizá-los. Personagens com nomes descritivos demais tendem a ser secundários nos romances, já que o nome, nesse caso, funciona como uma forma de abreviar a descrição e indicar se a personagem é "principal" ou "secundária", "esférica" ou "plana", "séria" ou "cômica" (p. 648). Pode-se acrescentar à teoria de Gallagher que personagens (ou figuras humanas) sem nome costumam ser menos importantes ainda, muitas vezes 
representados pela função ou profissão que exercem (o servente, o médico, a professora, etc.).

Em El otoño del patriarca, o nome do personagem principal nunca aparece. Geralmente ele é chamado por seus subalternos de mi general, e a denominação patriarca, do título, claramente se refere a ele, mas nenhum nome próprio verdadeiro é apresentado. Ao final do romance, aparece o nome Nicanor, mas é falso: Nicanor é como a morte chama a todos, no momento final (Márquez, 1980: p. 341). ${ }^{19} \mathrm{O}$ sobrenome, ao menos, deveria ser Alvarado - se Bendición Alvarado for realmente o nome da mãe do Patriarca, sobre quem ele erige uma mitologia, apresentada como falsa frente às descobertas do monsenhor Demetrio Aldous. ${ }^{20}$

O nome alegórico do personagem - "general" ou "Patriarca" - aproxima o romance da tradição descrita por Catherine Gallagher, na qual o nome descritivo encobre uma história pretensamente verdadeira e escandalosa. $O$ jogo com referentes históricos é evidente no romance. Na figura do Patriarca estão elementos da biografia de diversos ditadores latino-americanos, como "El Jefe" Rafael Trujillo (1897-1961), ditador da República Dominicana, ou Juan Vicente Gómez (1857-1935), da Venezuela. Consta que Gómez era semianalfabeto, o que foi transmutado no analfabetismo do Patriarca (que é, no quinto capítulo do romance, alfabetizado por Letícia Nazareno). Gómez também teria tido um grande número de filhos ilegítimos, o que no caso do Patriarca é exagerado para cinco mil. É Rafael Trujillo, porém, que parece concentrar o maior número de referências. Ditador da República Dominicada de 1930 a 1961, Trujillo tinha as mesmas preferências sexuais do Patriarca mulheres do povo, ou, na velhice, adolescentes, que eram trazidas por agentes que "persuadiam" as mulheres e suas famílias. Trujillo também tinha um problema urinário crônico, semelhante à hérnia no testículo que acompanha o Patriarca por toda a vida.

No plano público, Trujillo controlava por meio de empresas suas ou de sua família quase toda a riqueza do país, assim como o Patriarca faz no romance, no qual sua mãe Bendición Alvarado não sabe, mas é a mulher mais

\footnotetext{
${ }^{19} \mathrm{Na}$ edição brasileira, na página 252.

${ }^{20}$ Frente à tentativa de canonização de Bendición Alvarado pelo Patriarca após sua morte, o Vaticano envia o monsenhor Demetrio Alvous para investigar seu passado, ação que transcorre no quarto capítulo. 
rica da ilha caribenha. O culto de personalidade em torno ao ditador dominicano chegou ao absurdo de mudar o nome da capital do país, Santo Domingo, para Ciudad Trujillo (neste caso, a realidade superou a ficção). Como - Patriarca, Trujillo era obcecado pela limpeza pública. Também como o Patriarca, seu longo governo foi marcado pela perseguição política. ${ }^{21}$

Os nomes de outros personagens também têm funções descritivas. Seu sósia, Patrício Aragonés, contém a palavra "patrício", sua mãe, Bendición Alvarado, uma "bendição" no nome. Outros nomes descrevem de forma mais conotativa: Saturno Santos, o general índio que acaba sendo guarda-costas do Patriarca, evoca a figura do deus Saturno, o monstruoso deus rural do tempo que devorava os próprios filhos. O nome de Ignácio Saenz de la Barra, pela própria extensão e pelo rebuscamento de ter mais de um sobrenome, evoca ares aristocráticos. Letícia Nazareno tem a raiz latina de alegria no prenome e uma evocação religiosa no sobrenome.

O uso de uma técnica de nomeação característica do antigo romanesco indica que algo sobre a realidade pretende ser dito em El otoño. Segundo o próprio García Márquez, o Patriarca é um "personagem compósito", construído a partir de características de vários dos "velhos ditadores" do continente latinoamericano (em oposição aos "novos ditadores" tecnocratas) (BELL-VILLADA, 2006, p. 137). García Márquez representa essa passagem ao final do capítulo cinco e no capítulo seis de seu romance, quando o isolamento do Patriarca se completa e um aparelho repressivo similar ao das "novas ditaduras" tecnocráticas exerce o poder de fato.

\section{Fim da pré-história}

O narrador coletivo de El otoño del patriarca se apresenta elusivo, fugidio a quaisquer caracterizações rápidas. Pela forma que se apresenta, ele não pode ser simplesmente "o povo", mas creio que muito se perderia se ele fosse apenas uma miragem linguística e textual, uma amarra de fragmentos. Em minha leitura, o narrador representa os "outros" de qualquer sociedade autoritária, uma função que pode ser preenchida por diversos caracteres

${ }^{21}$ Utilizei como fontes para a comparação com Juan Vicente Gómez e Rafael Trujillo os estudos de Nemes (1975), Alvarado (2010) e Boldy (2010).

Revista Eletrônica Literatura e Autoritarismo: Narrativa Testemunhal e Relações Históricas - ISSN 1679-849X http://cascavel.ufsm.br/revistas/ojs-2.2.2/index.php/LA/index 
sociais de acordo com a situação. Mais que isso, esses "outros" - "nós" - inclui o leitor, que é chamado a participar da festa final, do júbilo pelo "fim do tempo da eternidade" - fim da pré-história e começo da História.

Em contraste com um narrador fragmentado que se unifica na leitura, 0 Patriarca, aparentemente um personagem fechado no texto, se revela uma montagem que encobre pedaços da realidade latino-americana. Por não ter nome, o personagem aproxima-se dos protagonistas dos antigos "romances escandalosos" - que, também, não deixavam de ser denúncias romanescas.

El otoño del patriarca convida o leitor a fazer parte do "nós, os outros" que narra o romance. Dessa perspectiva, de testemunha frente à imensa história de horrores do regime do Patriarca, o leitor não pode deixar de sentir a ambivalência da relação com essa personagem, um monstro, mas que desperta compaixão (conforme o próprio autor). Não se precisa dizer que a identificação com o mandatário é uma das características centrais do populismo latino-americano, um problema que não pode ser facilmente posto de lado em qualquer proposta política renovadora. Desvelar essa ambivalência entre monstruosidade e compaixão é apelar à liberdade do leitor, fazer com que ele pense o populismo em vez de ignorá-lo como parte do nosso pitoresco luso-hispânico.

\section{Referências}

ALVARADO, Douglas Augusto López. Mito, culto y represión em El otoño del patriarca. Cuestiones políticas, v. 26, n. 44, p. 34-54, jan-jun 2010.

BARSY, Kalman. La estructura dialéctica de El otoño del patriarca. Río Piedras: Editorial de la Universidad de Puerto Rico, 1989.

BELL-VILLADA, Gene H (Ed.). Conversations with Gabriel García Márquez. Jackson: University Press of Mississipi, 2006.

BENEDETTI, Mario. El recurso del supremo patriarca. Revista de Crítica Literaria Latinoamericana, ano 2, n. 3, p. 55-67, 1976.

BENVENISTE, Émile. Estrutura das relações de pessoa no verbo. In:

Problemas de linguística geral I. Campinas: Pontes, 1995. p. 247-259. 
BOLDY, Steven. The Autumn of the Patriarch. In: SWANSON, Phillip (ed.). The Cambridge Companion to Gabriel García Márquez. Cambridge: Cambridge University Press, 2010. p. 78-93.

BROTHERSTON, Gordon. The Secrets of Saturno Santos. Forum for Modern Language Studies, v. 15, n. 2, p. 144-149, 1979.

CÓRDOVA, José Hernán. Looking for the Indian in Columbus' Journal and García Márquez's The Autumn of the Patriarch. Alif: Journal of Comparative Poetics, Cairo, n. 4, p. 63-76, Spring 1984.

COROMINAS, J. Diccionario crítico etimológico de la lengua castellana. Madrid: Editorial Griedos, 1954. Volume III.

COSTA, Flávio Moreira da. García Márquez para presidente. O Pasquim, ano VII, n. 317, p. 17, 24 a 30 de julho de 1975.

ECHEVARRÍA, Roberto González. The Dicatorship of Rhethoric/The Rhetoric of Dictatorship: Carpentier, García Márquez, and Roa Bastos. Latin American Research Review, vol. 15, n. 3, p. 205-228, 1980.

ESCOSTEGUY, Jorge. El ditador. Veja, São Paulo, p. 111, 23 de junho de 1976.

GALLAGHER, Catherine. Ficção. In: MORETTI, Franco. A cultura do romance. São Paulo: Cosac \& Naify, 2009. p. 629-658.

LABANYI, Jo. Language and Power in El otoño del patriarca. In: CARDWELL, Richard, e MCGUIRK, Bernard (eds.). Gabriel García Márquez: New Readings. Cambridge: Cambridge UP, 1987. p. 135-150.

LIMA, Luiz Costa. Trilogia do controle: O controle do imaginário, Sociedade e discurso ficcional, O fingidor e o censor. São Paulo: Topbooks, 2007.

MADRIGAL, Luis Iñigo. García Márquez: una reflexión sobre el poder. Triunfo, ano XXX, n. 662, p. 72, jun. 1975.

MÁRQUEZ, Gabriel García. A imaginação no poder em Macondo. Entrevistador: Eduardo Bermejo. Cadernos de Opinião, Rio de Janeiro, n. 2, p. 51-55, 1975.

MÁRQUEZ, Gabriel García. El olor de la guayaba: conversaciones con Plinio Apuleyo Mendoza. Buenos Aires: Sudamericana, 1996.

MÁRQUEZ, Gabriel García. El otoño del patriarca. Barcelona: Club Bruguera, 1980;

MÁRQUEZ, Gabriel García. O outono do patriarca. Rio de Janeiro: Record, 1993.

NAVARRO, Márcia Hoppe. Romance de um ditador: poder e história na América Latina. São Paulo: İcone, 1989. 
NEMES, Graciela Palau de. El otoño del patriarca: historicidad de la novela. Hispamerica, v. 4, n. 11-12, p. 173-183, 1975.

ORTEGA, Julio. El otoño del patriarca: texto y cultura. Hispanic Review, vol. 46, n. 4, p. 421-446, Autumn 1978.

PANCORBO, Luis. Tres tristes tiranos. Revista de Occidente, Madrid, v. 19, p. 12-16, 1977.

RAMA, Ángel. Los dictadores latinoamericanos. México: Fondo de Cultura Económica, 1976.

ROBERTS, Gemma. El poder en lucha con la muerte: "El otoño del patriarca". Revista de archivos, bibliotecas y museos, Madrid, v. LXXIX, n. 2, p. 279-298, abril-junho 1976.

RIBEYRO, Julio Ramón. Algunas digresiones en torno a "El otoño del patriarca". Eco: Revista de la Cultura de Occidente, Bogotá, v. XXX/1, n. 187, p. 101-106, maio 1977.

SALDIVAR, Dasso. Acerca de la función política de la soledad en "El otoño del patriarca". La Estafeta Literária: Revista quincenal de libros, artes y espectáculos, Madrid, n. 561, p. 4-5, 1 de abril de 1975.

SCHWARTZ, Kessel. El otoño del patriarca. Hispania, v. 59, n. 3, p. 557, sep. 1976. Resenha.

SHAW, Donald. The Critical Reception of García Márquez. In: SWANSON, Philip. The Cambridge Companion to Gabriel García Márquez. Cambridge: Cambridge UP, 2010. p. 25-40.

WEST, Paul. The Posthumous Present (on The Autumn of the Patriarch). Review, n. 18, p. 76-78, 1976.

WOOD, Michael. Unhappy Dictators. The New York Reviw of Books, Nova lorque, v. 23, n. 20, p. 57-58, Dez. 1976. 